\title{
EFFECT OF SOME DRUGS ON HUMAN UMBILICAL ARTERY IN VITRO
}

\author{
BY \\ S. D. GOKHALE,* O. D. GULATI, $\dagger$ L. V. KELKAR AND V. V. KELKAR \\ From the Department of Pharmacology and the Pharmacological Research Unit, Council of Scientific \\ and Industrial Research, Medical College, Baroda, India
}

(Received March 1, 1966)

Investigation of the actions of drugs on vascular smooth muscle is frequently complicated by indirect actions mediated through neural elements. However, valuable information on the direct actions of drugs on vascular smooth muscle can often be obtained from experiments on nerve-free preparations. Perfused placental vessels (von Euler, 1938 ; Panigel, 1962), spirally cut umbilical arterial and venous strips (Somlyo, Woo \& Somlyo, 1965), chick amniotic membrane (Ferguson, 1940 ; Cuthbert, 1963), and rabbit ear vessels before innervation (Clark \& Clark, 1943) have been employed in the past for this purpose. A nerve-free vascular smooth muscle preparation, responding uniformly to various autonomic transmitters could also be used to elucidate the nature of their storage and release.

In the present study the isolated perfused human umbilical artery was used to study the direct action of drugs on the vascular smooth muscle. It was observed that with the method employed many vasoactive agents gave fairly uniform responses. Modification of these responses by other drugs could, therefore, be studied. The preparation exhibited spontaneous tone and could give a dilator response to drugs, without the previous addition of a spasmogenic agent.

\section{METHODS}

Umbilical cords were obtained from the Maternity Ward of Shree Sayaji General Hospital, Baroda, as soon after delivery as possible. After identifying the foetal and the placental ends, every cord was firmly tied at both ends and kept in a flask containing perfusion fluid of the following composition (g/1.): sodium chloride, 9.00 ; potassium chloride, 0.42 ; calcium chloride, 0.24 , sodium bicarbonate, 0.2 and dextrose, 1.0. Tying ensured that any blood in the lumen of the vessels remained in a fluid state and could subsequently be washed out easily. In earlier experiments when the cords were not tied, many of them could not be used because of the intravascular clotting. The cords remained viable for about $5 \mathrm{hr}$ after delivery. Experiments were, therefore, started soon after the collection of the cords.

Before cannulation the cords were placed in fresh perfusion fluid at $34^{\circ} \mathrm{C}$ for $10 \mathrm{~min}$. This considerably reduced the spasm of the vessels and thus facilitated cannulation. A piece of cord about 5 in. long was selected (excluding any portion with injury and pseudoknots), and this was cut at both ends with a sharp pair of scissors. One of the umbilical arteries was cannulated at the

\footnotetext{
* Present address: Government Medical College, Surat.

$\dagger$ Reprint requests may be sent to $O$. D. Gulati.

$\ddagger$ Present address: B.J. Medical College, Ahmedabad.
} 
foetal end with a B.D. No. 18 venesection needle and perfusion fluid at $34^{\circ} \mathrm{C}$ was very gently pushed through the needle to wash out blood.

The placental end of the artery was cannulated with a polyethylene tube. The cord was now vertically fixed, with the foetal end up, in a glass bath containing perfusion fluid maintained at $34^{\circ} \mathrm{C}$. Perfusion was of the gravity type and was effected by allowing fluid gassed with $5 \% \mathrm{CO}_{2}$ in $\mathrm{O}_{2}$ to flow from a Mariotte bottle through the cannula in the foetal end of the vessel. Perfusion pressure was adjusted by raising or lowering the Mariotte bottle and ranged in different experiments from 40 to $60 \mathrm{~mm} \mathrm{Hg}$. The $p \mathrm{H}$ of the perfusion fluid on the outflow side was 7.3 to 7.4. The polyethylene tube at the placental end of the vessel led the outflow through the floor of the glass bath to a Gaddum outflow Recorder connected to a piston recorder writing on smoked kymograph paper: The outflow ranged from 6 to $12 \mathrm{ml} . / \mathrm{min}$.

Particular care was taken to maintain the temperature of the perfusion fluid constant at $34^{\circ} \mathrm{C}$ both in the Mariotte bottle and the bath, as reactivity was rapidly lost above $36^{\circ} \mathrm{C}$ and the preparation went into spasm below $31^{\circ} \mathrm{C}$.

The drugs to be tested were diluted in saline and were injected in a fixed volume of $0.3 \mathrm{ml}$. through the rubber tubing, close to the foetal end of the vessel. The interval between successive administration of drugs varied from 7 to $10 \mathrm{~min}$.

A total of 70 preparations were set up.

Drugs :

Acetylcholine chloride, $( \pm$ )-noradrenaline hydrochloride, 5-hydroxytryptamine creatinine sulphate, histamine acid phosphate, isoprenaline sulphate, atropine sulphate, hyoscine hydrobromide, physostigmine salicylate, dihydroergotamine methanesulphonate, phentolamine methanesulphonate, cyproheptadine hydrochloride, pronethalol hydrochloride, morphine sulphate, mepyramine maleate, antazoline methane sulphonate, papaverine hydrochloride and caffeine citrate were used throughout the experiments. Their doses are expressed in terms of the base. Doses of calcium chloride, potassium chloride, barium chloride and sodium nitrite are expressed in terms of the salts. Adrenaline base, angiotensin, synthetic bradykinin, posterior pituitary extract, synthetic oxytocin, aminophylline, digoxin, bromolysergic acid diethylamide (BOL) were prepared in $0.9 \%$ saline immediately before use.

\section{RESULTS}

In most of the experiments the rate of outflow gradually increased during the initial 15 to $30 \mathrm{~min}$ of perfusion. Thereafter the outflow remained constant for 2 to $4 \mathrm{hr}$. Study of drug effects was, therefore, limited to this period.

Spontaneous variations in tone were not observed during individual experiments.

\section{Effect of acetylcholine}

The response to acetylcholine increased during the initial $45 \mathrm{~min}$ of perfusion, but thereafter reproducible responses were obtained for 60 to $90 \mathrm{~min}$. Of a total of 26 preparations exposed to acetylcholine $(0.8$ to $80 \mu \mathrm{g}) 12$ gave a constrictor response lasting for 2 to $5 \mathrm{~min}, 8$ gave a dilator response lasting for 2 to $3 \mathrm{~min}$ and 6 did not respond. The constrictor response was related to the dose of acetylcholine (Fig. 1) but a clear-cut dose/response relationship could not be obtained with the dilator response. Physostigmine $(66.6$ to $133.2 \mu \mathrm{g})$ injected over a period of $3 \mathrm{~min}$ had no action of its own on the vessel, nor were responses to acetylcholine altered after the administration of physostigmine.

Antagonists : Atropine $(2.0$ to $6.3 \mu \mathrm{g})$ injected over a period of $3 \mathrm{~min}$ had no action on the vessel but blocked the constrictor (Fig. 1) as well as the dilator responses to acetylcholine. The blocking action of atropine lasted for 30 to $40 \mathrm{~min}$. At the end of this 


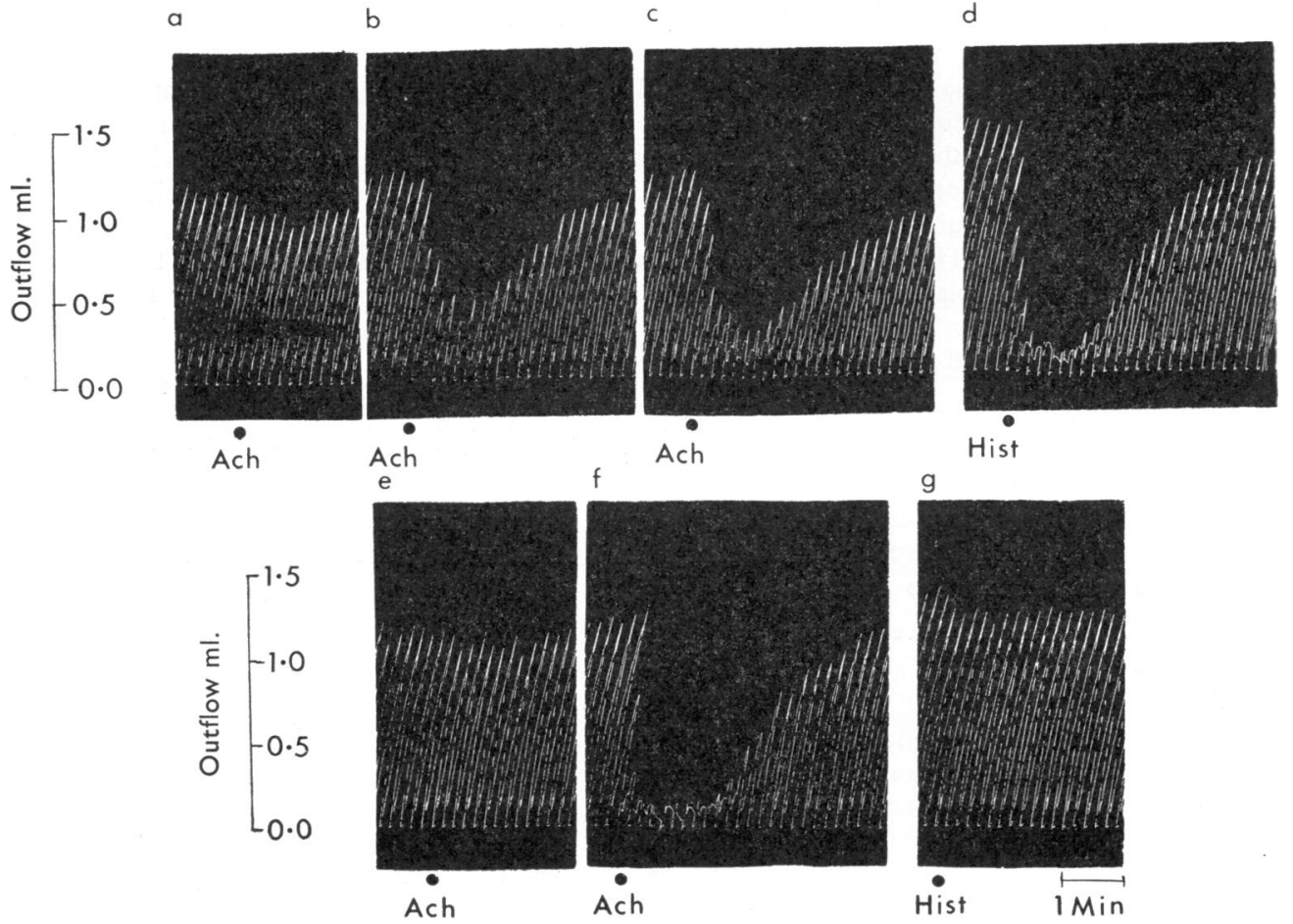

Fig. 1. Perfused human umbilical artery. Records of outflow/10 sec. Constrictor responses to acetylcholine at (Ach), $(8 \mu \mathrm{g}$ in a), $(16 \mu \mathrm{g}$ in b), and $(24 \mu \mathrm{g}$ in $\mathrm{c}$ and $\mathrm{e})$; to histamine at (Hist) $(3.6 \mu \mathrm{g}$ in $\mathrm{d}, \mathrm{f}$ and $\mathrm{g})$. Between $\mathrm{c}$ and $\mathrm{d}, 6.3 \mu \mathrm{g}$ of atropine was slowly infused over a period of $3 \mathrm{~min}$; between $\mathrm{f}$ and $\mathrm{g}, 99.3 \mu \mathrm{g}$ of mepyramine was infused similarly. Atropine blocked the action of acetylcholine but had no effect on histamine induced constriction which was blocked by mepyramine.

period responses to acetylcholine were completely restored. Hyoscine $(6.9 \mu \mathrm{g})$ also similarly blocked the responses of the artery to acetylcholine. Antazoline (73.5 to 294 $\mu \mathrm{g})$ did not alter the responses to acetylcholine.

\section{Effect of adrenaline and noradrenaline}

After about $1 \mathrm{hr}$ of perfusion the preparations gave reproducible responses to adrenaline and noradrenaline.

Of a total of 32 preparations 17 gave a constrictor response to adrenaline $(0.01$ to 50 $\mu \mathrm{g}), 7$ gave a dilator response and 8 gave no response. Of a total of 23 preparations 13 gave a constrictor response to noradrenaline $(0.016$ to $123 \mu \mathrm{g}), 4$ gave a dilator response and 6 did not respond. While the constrictor response was related to dose (Fig. 2), no clear-cut dose/response relationship was observed in the case of the dilator response. The responses lasted for 1 to $3 \mathrm{~min}$. In the majority of experiments sensitivity of the preparations to amines remained constant for 1 to $2 \mathrm{hr}$ and declined but very slowly even over prolonged periods of perfusion. In a few cases the vessels became rapidly insensitive to the amines. 

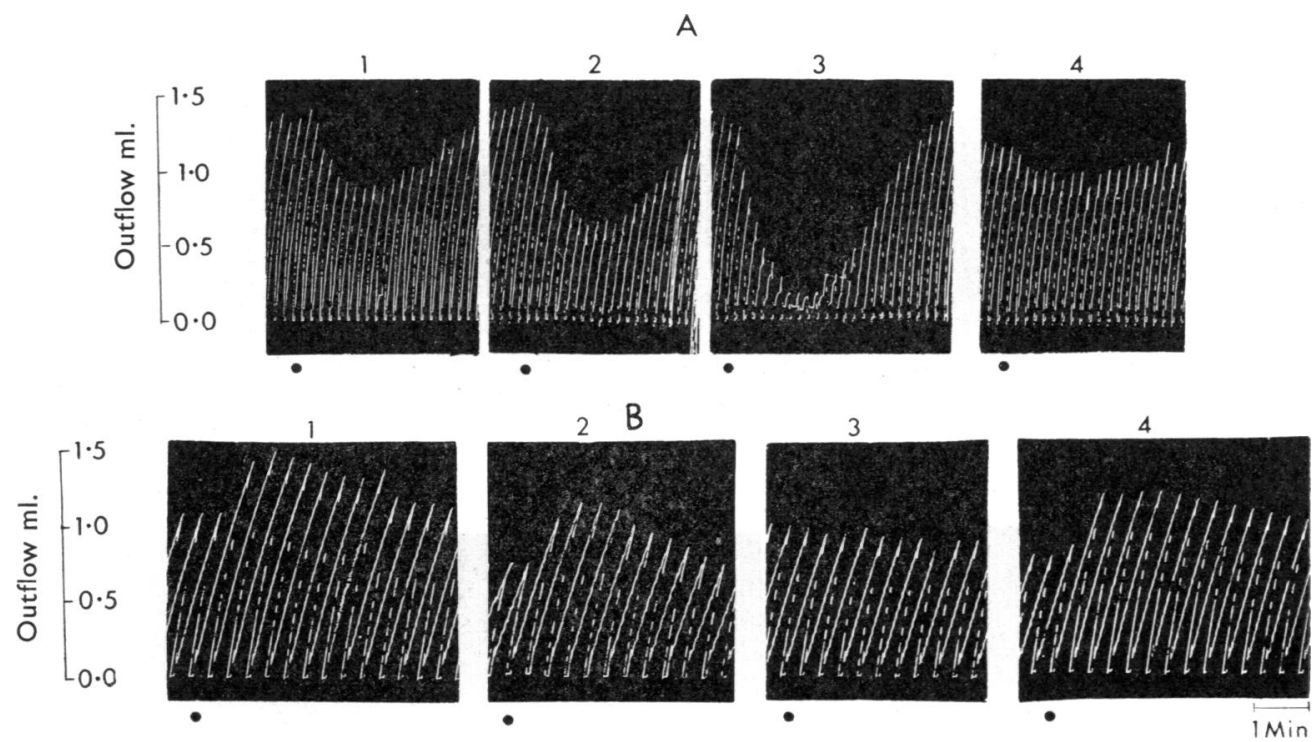

Fig. 2. Perfused human umbilical artery. Records of outflow/10 sec in (A) and /20 sec in (B). Records in $A$ and $B$ are from different preparations. In (A), effect of adrenaline (given at dots), $(0.1 \mu \mathrm{g}$ in 1$),(0.15 \mu \mathrm{g}$ in 2$)$, and $(0.2 \mu \mathrm{g}$ in 3 and 4$)$. Record 4 was obtained 4 min after phentolamine, $75 \mu \mathrm{g}$, slowly infused over a period of $4 \mathrm{~min}$. In (B), effect of adrenaline (10 $\mu \mathrm{g}$ given at dots), before (in 1), $3 \mathrm{~min}$ after pronethalol ( $86 \mu \mathrm{g}$, slowly infused over a period of $4 \mathrm{~min}$ in 2), and $3 \mathrm{~min}$ after phentolamine, (75 $\mu \mathrm{g}$ in 3) given slowly over a period of $4 \mathrm{~min}$. Record 4 was obtained after $40 \mathrm{~min}$ of continued perfusion.

Antagonists : Dihydroergotamine $(9.2$ to $23.1 \mu \mathrm{g})$ and phentolamine $(9.0$ to $298.0 \mu \mathrm{g})$ were administered either rapidly or over a period of 2 to $5 \mathrm{~min}$. Dihydroergotamine administered rapidly produced a constriction of the artery. When the same dose of dihydroergotamine was repeated after $7 \mathrm{~min}$, the constrictor response was either considerably reduced or was absent. Phentolamine had no effect on the preparation.

Both constrictor and dilator responses to adrenaline and noradrenaline were totally blocked following treatment with dihydroergotamine or phentolamine (Fig. 2). Recovery occurred after 20 to $60 \mathrm{~min}$. The dilator response could not be blocked by pronethalol (43.2 to $129.5 \mu \mathrm{g}$; Fig. 2).

Atropine $(2.0$ to $6.3 \mu \mathrm{g})$ or antazoline $(73.5$ to $294 \mu \mathrm{g})$ had no effect on the responses.

\section{Effect of Isoprenaline}

Since adrenaline and noradrenaline produced dilator responses in some preparations it was of interest to study the effect of isoprenaline. In five experiments isoprenaline $(0.75$ to $227.7 \mu \mathrm{g}$ ) failed to evoke any response in the umbilical artery.

\section{Effect of 5-hydroxytryptamine}

After $60 \mathrm{~min}$ of perfusion, consistent constrictor responses to 5-hydroxytryptamine $(0.002$ to $1.4 \mu \mathrm{g}$, given at intervals of 7 to $10 \mathrm{~min}$ ) were elicited for 2 to $3 \mathrm{hr}$ (13 experiments). The responses lasted for 1 to $4 \mathrm{~min}$ and were dose-related (Fig. 3). A constrictor response was often preceded by an evanescent dilator response. In a few 


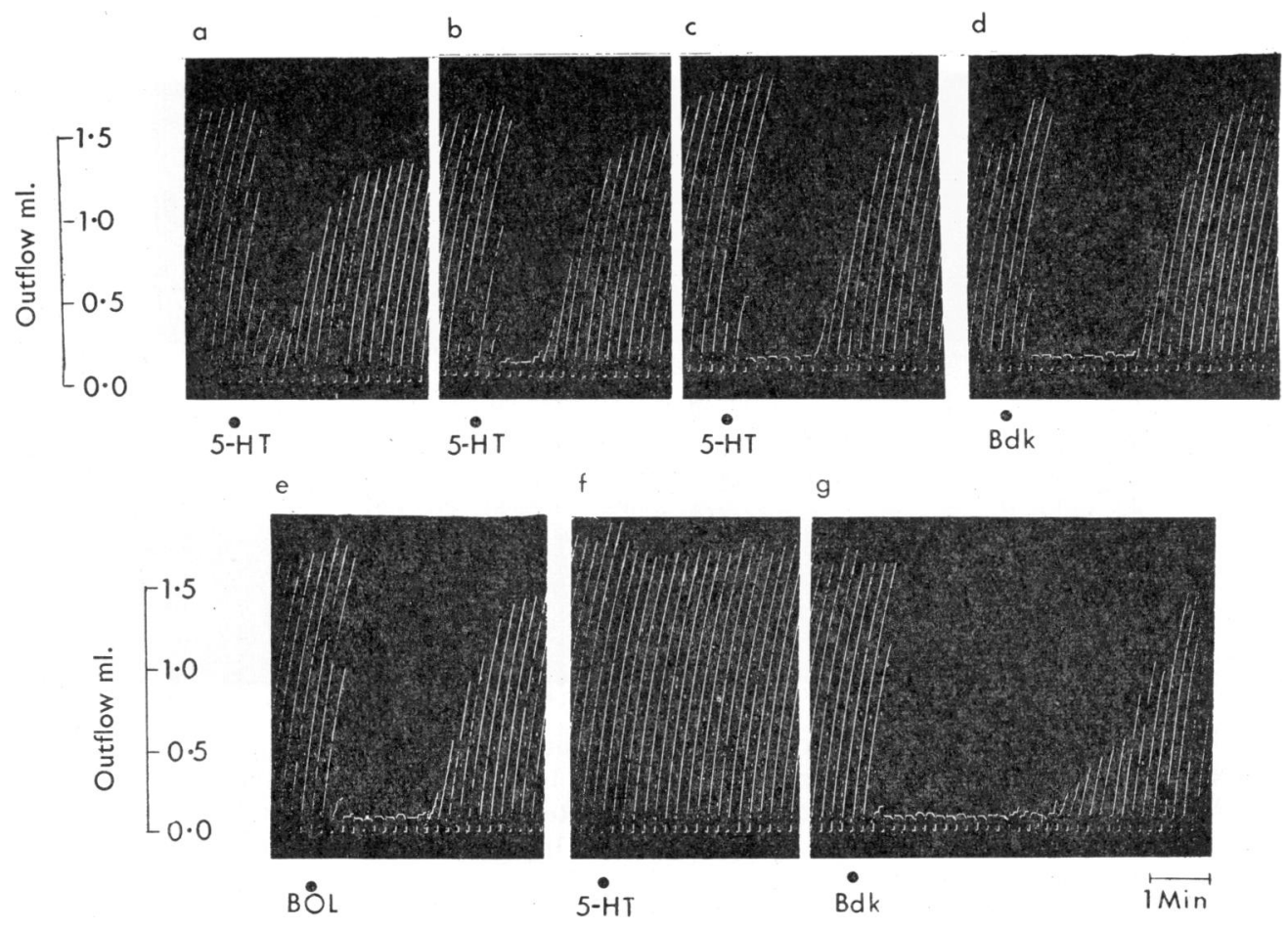

Fig. 3. Perfused human umbilical artery. Records of outflow/10 sec. Responses to 5-hydroxytryptamine at (5-HT), $(0.01 \mu \mathrm{g}$ in a), $(0.015 \mu \mathrm{g}$ in b), and $(0.02 \mu \mathrm{g}$ in $\mathrm{c}$ and $\mathrm{f})$; to synthetic bradykinin at (Bdk), $(0.5 \mu \mathrm{g}$ in $\mathrm{d}$ and $\mathrm{g})$; and to bromolysergic acid diethylamide at (BOL), $(10 \mu \mathrm{g}$ in $\mathrm{e})$. Record $\mathrm{f}$ was obtained $8 \mathrm{~min}$ after the injection of BOL. 5-Hydroxytryptamine induced a doserelated constriction. BOL also constricted the vessel, and blocked the effect of 5-hydroxytryptamine given subsequently. The constriction induced by bradykinin was augmented after BOL.

experiments vasoconstriction was followed by vasodilatation. In two experiments 5 hydroxytryptamine elicited only a dilator response.

Antagonists : BOL (10 to $15 \mu \mathrm{g}$ ) given rapidly or over a period of $3 \mathrm{~min}$ had no effect on the vessel in two experiments. In one experiment it gave a constrictor response when given rapidly. The constrictor and dilator actions of 5-hydroxytryptamine were totally blocked following BOL (Fig. 3).

Cyproheptadine (19.8 to $339.0 \mu \mathrm{g}$ ) given over a period of $3 \mathrm{~min}$ or rapidly had no effect on the vessel, but abolished the responses to 5-hydroxytryptamine for 10 to 30 $\min$.

Atropine $(2$ to $6.3 \mu \mathrm{g})$ failed to block responses to 5-hydroxytryptamine.

\section{Effect of histamine}

The sensitivity to histamine gradually increased during the initial 20 to $30 \mathrm{~min}$ of perfusion but remained fairly constant thereafter for 1 to $3.5 \mathrm{hr}$. Histamine $(0.36$ to 
$18.0 \mu \mathrm{g})$ induced a powerful constriction which was often preceded by transient dilatation (12 experiments, Fig. 4).

One preparation gave a purely dilator response. The constrictor response which lasted for 1 to $4 \mathrm{~min}$ was related to dose.

Antagonists : In five experiments antazoline ( $36.7 \mu \mathrm{g}$ to $1.5 \mathrm{mg}$ ) administered rapidly or slowly over a period of $3 \mathrm{~min}$ had no effect of its own on the vessel, but abolished both the constrictor and the dilator responses to histamine (Fig. 4). However, the initial dilator response to histamine was more resistant to blockade by antazoline. Antazoline $(100 \mu \mathrm{g})$ given at the height of a histamine-induced constriction did not modify it (two experiments). In six experiments mepyramine (16.5 to $132.3 \mu \mathrm{g})$ given either as a single dose or as an infusion over a period of $3 \mathrm{~min}$ had no effect of its own on the umbilical artery but totally blocked the responses to histamine. The blockade of histamine-induced responses by antazoline or mepyramine persisted for 20 to $40 \mathrm{~min}$. The dilator component of histamine action often recovered first.

Atropine ( 2 to $6.3 \mu \mathrm{g}$ ), hyoscine $(6.9 \mu \mathrm{g})$, phentolamine (37.0 to $150.0 \mu \mathrm{g}$ ) and dihydroergotamine 9.2 to $23.0 \mu \mathrm{g}$ ), which were effective in blocking responses to their respective agonists, failed to block responses to histamine.

The dilatation caused by histamine was not affected by pronethalol (43 to $129.5 \mu \mathrm{g}$ ).

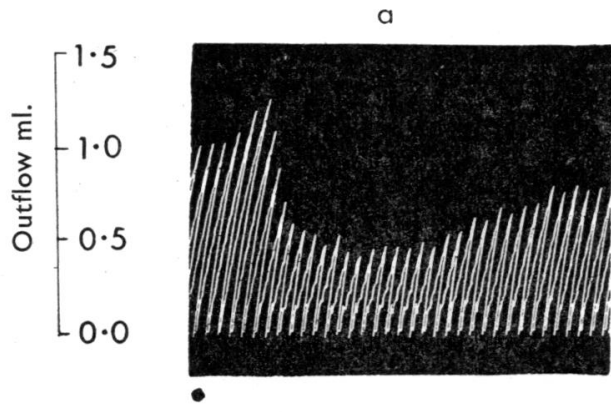

d

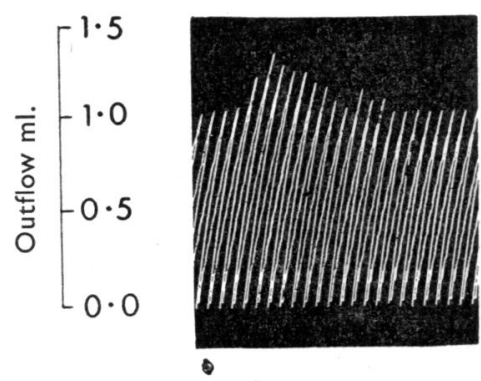

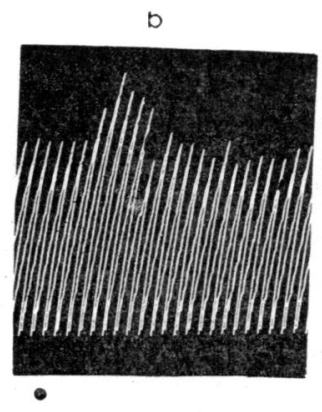

e

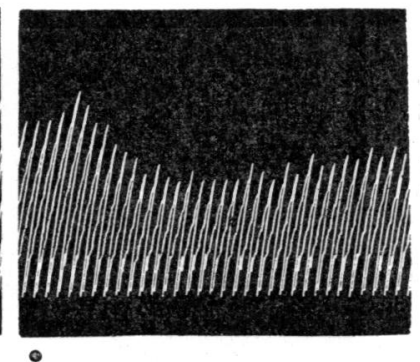

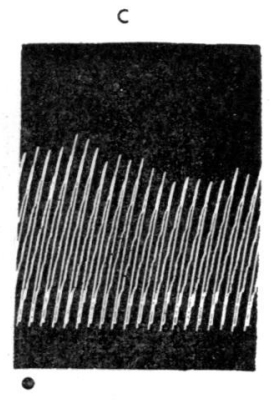

f

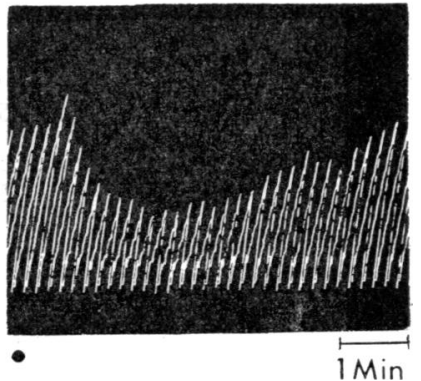

Fig. 4. Perfused human umbilical artery. Records of outflow/10 sec. Responses to histamine $1.8 \mu \mathrm{g}$ (given at dots). Between a and $\mathrm{b}$, antazoline $75 \mu \mathrm{g}$ was slowly given over a period of $3 \mathrm{~min}$, and was repeated between $b$ and $c$. Records $d$, e, and $f$ were obtained 15, 20 and $40 \mathrm{~min}$ respectively after the last injection of antazoline. The constrictor component of the response to histamine was blocked readily by antazoline, while the dilator component could be blocked only by the higher doses of antazoline. The dilator component recovered earlier than the constrictor component. 


\section{Effect of bradykinin}

Bradykinin produces hypotension in a variety of animal species (Lewis, 1960 ; Konzett \& Stürmer, 1960 ; Stürmer \& Berde, 1962 ; Parratt, 1964), though a pressor response has also been reported under certain circumstances (Croxatto \& Belmer, 1961). A potent coronary vasodilator action of bradykinin has been reported by Antonio \& Rocha e Silva (1962) and Parratt (1964).

After $1 \mathrm{hr}$ of perfusion the umbilical artery gave consistent constrictor response to bradykinin ( 0.5 to $1 \mu \mathrm{g}$, given at 7 to $10 \mathrm{~min}$ intervals) for 2 to $4 \mathrm{hr}$ (nine experiments). The response lasted for 1 to $4 \mathrm{~min}$ and was related to dose (Fig. 5).

Antagonists: Phentolamine (37.3 to $149.0 \mu \mathrm{g}$ ), atropine $(2.0$ to $13.0 \mu \mathrm{g}$ ) and cyproheptadine $(89.8 \mu \mathrm{g})$ given over a period of $3 \mathrm{~min}$ did not alter bradykinin-induced contraction of the vessel. BOL (10 to $15 \mu \mathrm{g}$ ) had either no effect (two experiments) or potentiated (one experiment) the responses to bradykinin.

In three experiments acetyl salicylic acid $(8$ to $16 \mathrm{mg})$ slowly infused over a period of 5 to $6 \mathrm{~min}$ had no effect on the responses of the artery to 5-hydroxytryptamine, but substantially reduced the constrictor response to bradykinin (Fig. 5).

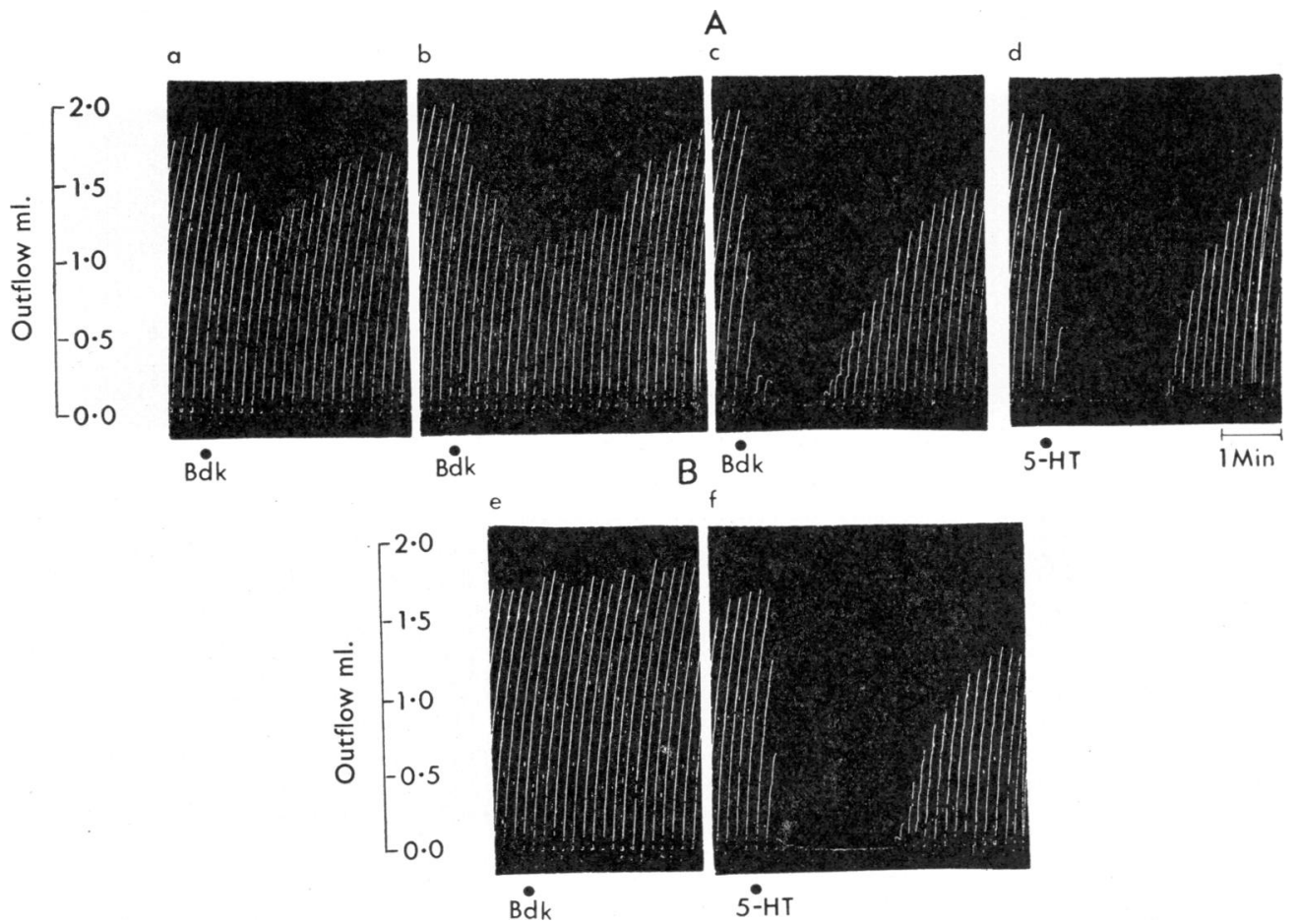

Fig. 5. Perfused human umbilical artery. Records of outflow/10 sec. Responses (at dots) to synthetic bradykinin at (Bdk), $(0.2 \mu \mathrm{g}$ in a), $(0.4 \mu \mathrm{g}$ in b) and $(0.6 \mu \mathrm{g}$ in $\mathrm{c}$ and $\mathrm{e})$; and to 5-hydroxytryptamine at $(5-\mathrm{HT}),(0.023 \mu \mathrm{g}$ in $\mathrm{d}$ and $\mathrm{f})$. Between $\mathrm{A}$ and $\mathrm{B}, 10 \mathrm{mg}$ of acetylsalicylic acid was slowly infused over a period of $5 \mathrm{~min}$. Bradykinin produced a dose-related constriction. Acetylsalicylic acid blocked the effect of bradykinin but did not affect the constriction induced by 5-hydroxytryptamine. 


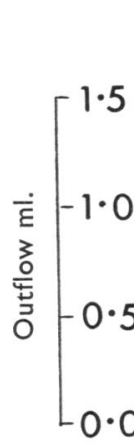

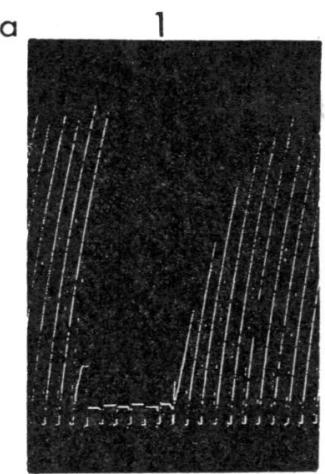
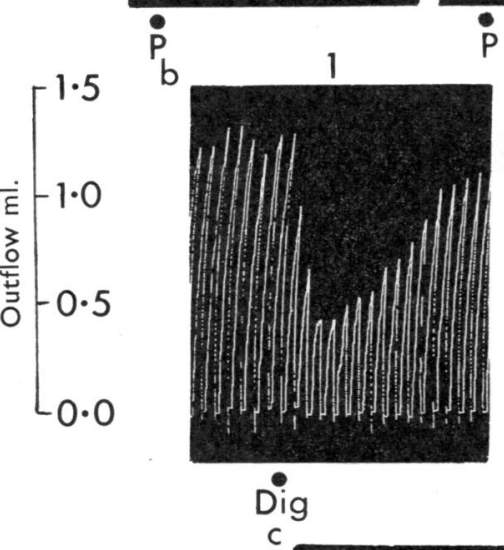

Dig
2

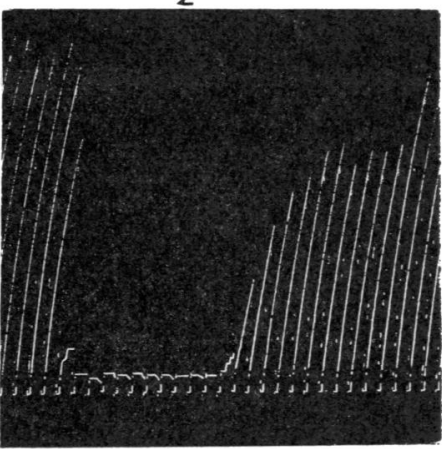

$\dot{\mathrm{P}}$

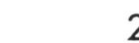

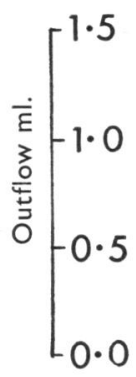
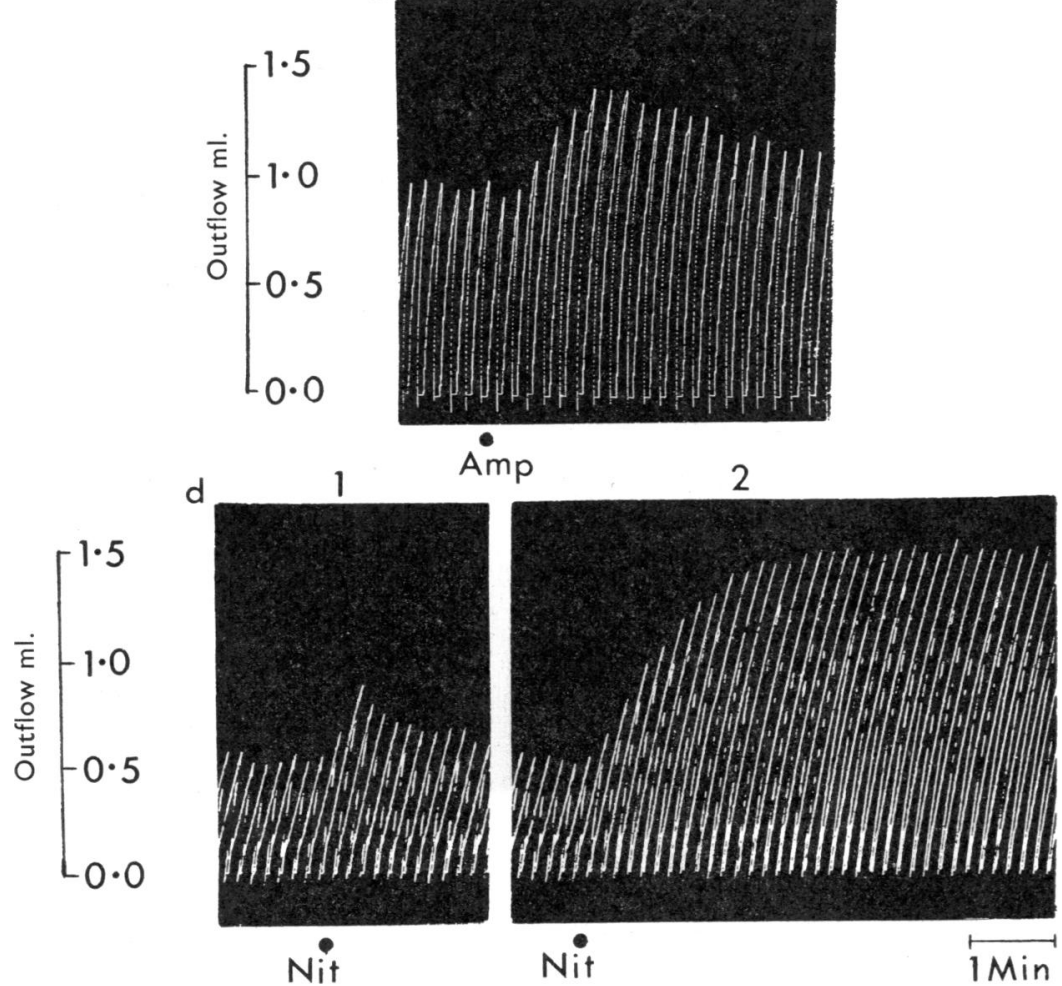

Fig. 6. Perfused human umbilical artery. Records of outflow/10 sec. Constrictor responses at (dots) to posterior pituitary extract at $(\mathrm{P}),(0.25 \mathrm{U}$ in 1 a) and $(0.5 \mathrm{U}$ in 2 a); and to digoxin at (Dig), $(12.5 \mu \mathrm{g}$ in $1 \mathrm{~b})$ and $(25 \mu \mathrm{g}$ in $2 \mathrm{~b})$. Dilator responses to aminophylline at (Amp), (500 $\mu \mathrm{g}$ in c) and to sodium nitrite at (Nit), $(1.5 \mathrm{mg}$ in $1 \mathrm{~d})$ and $(3.5 \mathrm{mg}$ in $2 \mathrm{~d})$. Records $\mathrm{a}, \mathrm{b}, \mathrm{c}$ and $\mathrm{d}$ are from different preparations. 

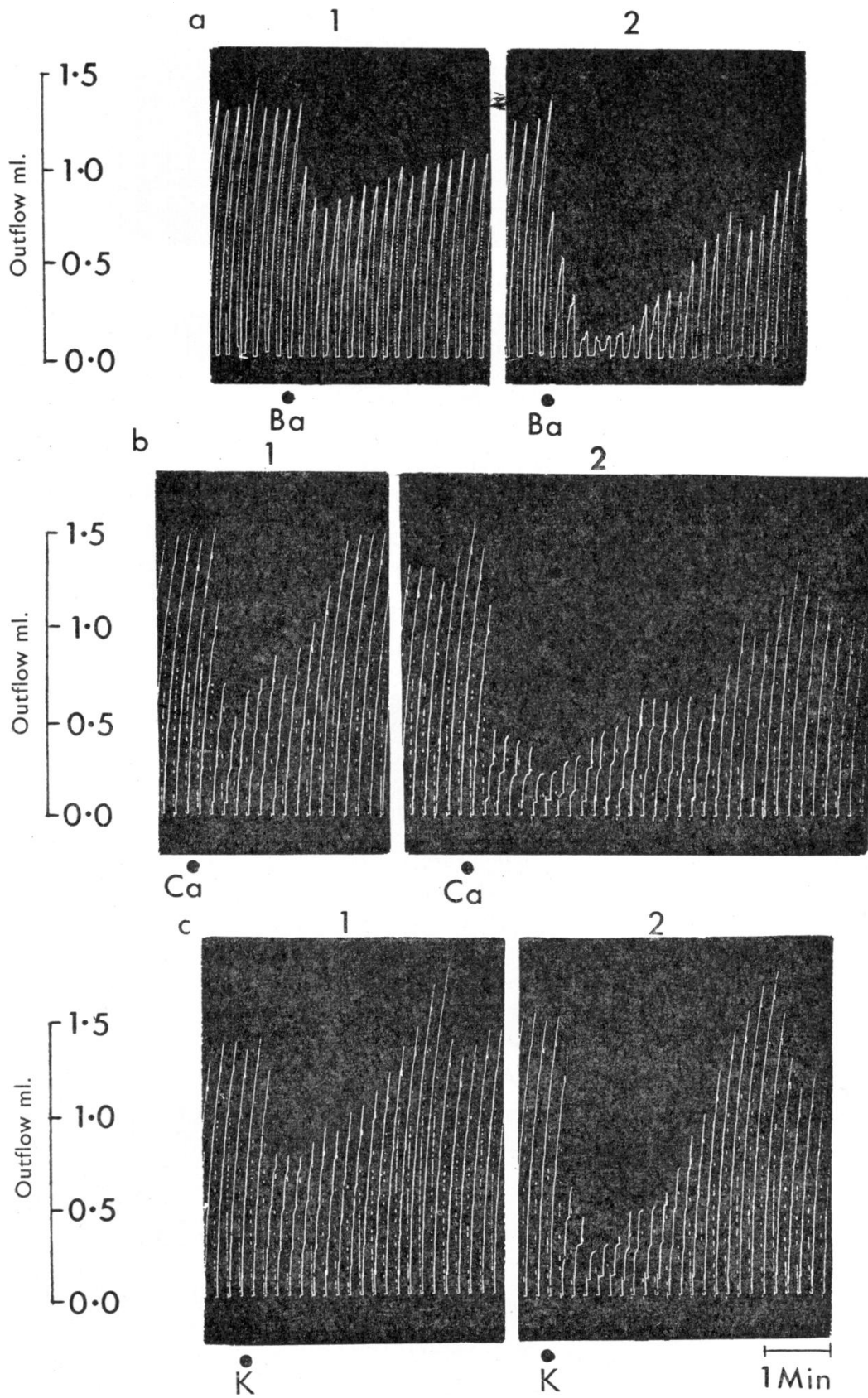

Fig. 7. Perfused human umbilical artery. Records of outflow/10 sec. Constrictor responses to. barium chloride at $(\mathrm{Ba}),(10 \mu \mathrm{g}$ in $1 \mathrm{a})$ and $(15 \mu \mathrm{g}$ in $2 \mathrm{a})$; to calcium chloride at $(\mathrm{Ca}),(5 \mathrm{mg}$ in $1 \mathrm{~b})$ and $(10 \mathrm{mg}$ in $2 \mathrm{~b}$ ); and to potassium chloride at (K), (10 $\mathrm{mg}$ in $1 \mathrm{c})$ and $(15 \mathrm{mg}$ in $2 \mathrm{c}$ ). Records $a, b$, and $c$ are from different preparations. 


\section{Effect of angiotensin}

In five experiments angiotensin $(1$ to $50 \mu \mathrm{g})$ was found to be without any effect on the umbilical artery although these preparations were very sensitive to noradrenaline.

\section{Effect of posterior pituitary extract and synthetic oxytocin and digoxin}

Reproducible responses of the umbilical artery to posterior pituitary extract and oxytocin could be obtained after $1 \mathrm{hr}$ of perfusion. In four experiments posterior pituitary extract $(0.25$ to $1 \mathrm{U})$ or oxytocin $(0.12$ to $2 \mathrm{U})$ given rapidly elicited a constrictor response lasting for 1 to $3 \mathrm{~min}$. The response was related to dose (Fig. 6). Oxytocin elicited dilator response in three other experiments. The dilator response was not related to dose ; in fact, sensitivity of the preparation decreased as the experiment progressed.

The preparation responded to digoxin $(12.5$ to $50 \mu \mathrm{g})$ with a dose-related constriction (three experiments, Fig. 6).

\section{Effect of barium chloride, calcium chloride and potassium chloride}

In three experiments barium chloride (10 to $45 \mu \mathrm{g}$ ) elicited a dose-related constrictor response (Fig. 7) confirming the findings of Ueda (1931). Dose-related constrictor responses were also elicited with calcium chloride $(5$ to $20 \mathrm{mg}$ ) in three experiments (Fig. 7) and with potassium chloride (10 to $30 \mathrm{mg}$ ) in three experiments (Fig. 7).

\section{Effect of papaverine, caffeine, aminophylline and sodium nitrite}

Three preparations were insensitive to papaverine $(94 \mu \mathrm{g}$ to $37.8 \mathrm{mg})$; in two others a moderate constrictor response was observed.

Caffeine $(0.5$ to $2.0 \mathrm{mg})$ elicited a moderate dose-related dilator response, the duration of which varied from 1.5 to $3 \mathrm{~min}$ (three experiments). Aminophylline $(0.1$ to $1.0 \mathrm{mg}$ ) produced arterial dilatation lasting for 1 to $3 \mathrm{~min}$ (eight experiments, Fig. 6).

Sodium nitrite ( 1.5 to $3.5 \mathrm{mg}$ ) gave a dose-related dilator response (seven experiments, Fig. 6) lasting for 2 to $4 \mathrm{~min}$. The dilator response was very well marked if the initial tone of the artery was high. Doses higher than $3.5 \mathrm{mg}$ produced irreversible dilatation (Fig. 6).

\section{DISCUSSION}

Spontaneous variations in tone exhibited by various isolated smooth muscle preparations often interfere with quantitative determinations of dose-response relationships for drugs. Spontaneous variations in tone were not observed in the present study.

The vasodilator action of cholinergic drugs on various vascular beds is well documented. There is also evidence for a constrictor action of acetylcholine on pulmonary vascular (Nuki, 1954) and coeliac venous beds (Fleisch, 1931), and on isolated strips of large arteries and veins. The antagonistic effect of atropine on acetylcholine-induced constriction and dilatation of the umbilical artery observed in the present study suggests a direct action of acetylcholine on muscarinic receptors which subserve a motor as well as an inhibitory function.

Acetylcholine is endogenously produced unassociated with nervous elements in a number of spontaneously active tissues (Comline, 1946 ; Bülbring, Burn \& Shelley, 1953 ; Feldberg \& Lin, 1950). However, physostigmine had no action on the preparation nor 
could it modify the action of acetylcholine. The stimulant action of physostigmine on the nerve free smooth muscle of chick amnion reported by Cuthbert (1962) was explained on the basis of a rapid passage of the drug to an intracellular locus, where it probably inhibited cholinesterase. In the umbilical artery the inactivity of physostigmine might be due to a lack of endogenous production of acetylcholine or to absence of cholinesterase.

The constriction of the vessel induced by adrenaline or noradrenaline was unaffected by atropine or antazoline but was blocked by dihydroergotamine and phentolamine. The dilator response to the amines was also blocked by phentolamine but not by pronethalol, which otherwise specifically blocks the inhibitory responses to catecholamines (Black \& Stephenson, 1962). Moreover, isoprenaline which predominantly acts on $\beta$-adrenergic receptors failed to cause a dilator response. These observations suggest that there are no $\beta$-adrenergic receptors in the human umbilical artery and that catecholamines act specifically on $\alpha$-receptors to produce a motor as well as an inhibitor response.

The preparation showed considerable variation in sensitivity to acetylcholine, adrenaline and noradrenaline. It is possible that though innervation is not essential for high sensitivity of a tissue to neurotransmitters, it might in some way be necessary for uniform responses to these substances. The variation in sensitivity to amines confirms the findings of previous workers (Takenaka, 1963 ; von Euler, 1938).

The vascular responses to 5-hydroxytryptamine in vivo depend upon cardiovascular reactivity (Page \& McCubbin, 1953). Measures which change the amount of neurogenic tone change the response to 5-hydroxytryptamine most effectively. Nerve-free vascular smooth muscle preparations are, therefore, of value in the investigation of the direct action of 5-hydroxytryptamine, which induced a uniform and powerful constriction of the umbilical artery. High sensitivity of the umbilical circulatory bed to 5-hydroxytryptamine has also been repeatedly observed in the past (Takaneka, 1963; Panigel, 1959 ; Somlyo et al., 1965). In agreement with the findings of Aström \& Samelius (1957) 5-hydroxytryptamine was found to be a more potent constrictor than adrenaline. BOL and cyproheptadine blocked the action of 5-hydroxytryptamine, suggesting the presence of distinct receptors in the umbilical artery. The tachyphylaxis reported for 5-hydroxytryptamine with other preparations (Reid \& Rand, 1952; Freyburger, Graham, Rapport, Seay, Govier, Swoap \& Vander Brook, 1952) did not occur with the perfused human umbilical artery.

Histamine produced a powerful constriction of the umbilical artery and it is suggested that the rise in blood histaminase levels during pregnancy might be teleologically related to this constrictor action of histamine. The constrictor response to histamine, easily blocked by antihistaminics but not by atropine, may be attributed to the presence of motor histaminergic receptor. Specific inhibitory histaminergio receptor also appears to be present since the dilator effect of histamine was blocked by antazoline but not by atropine or pronethalol. Furchgott (1954) has indicated the possibility of the existence of these two types of receptors for histamine in other smooth muscles.

The powerful constrictor effect of bradykinin on the umbilical artery is rather unusual, as the polypeptide commonly dilates vessels in different beds. The constrictor effect was not blocked by phentolamine, atropine, cyproheptadine or BOL but was suppressed by 
acetyl salicylic acid, suggesting a close similarity between sites of action of bradykinin in umbilical artery and those in other smooth muscle where a similar antagonism is observed (Collier \& Shorley, 1960; Collier, Holgate, Schachter \& Shorley, 1960; Collier, 1963).

Posterior pituitary extract and oxytocin induced constriction of the umbilical artery in a closely similar dosage range. In general this is in agreement with the observation of Somlyo et al. (1965). The significance of oxytocin-induced constriction of the vessel is not clear although low oxygen saturation of umbilical venous blood during administration of oxytocin to mother has been found (Corbit, 1962). In the present study, moreover, oxytocin produced dilatation of the vessels in some experiments and neither posterior pituitary extract nor oxytocin exhibited the high order of potency reported by Somlyo et al. (1965).

Thus bradykinin and oxytocin, the naturally occurring small polypeptides with vascular and uterine contracting effects, appear to exhibit an additional effect in common, that of contracting the umbilical artery.

The constrictor response elicited by papaverine in two of the five preparations is in contrast to the findings of Panigel (1962) who demonstrated a powerful dilatation with papaverine. A powerful dilatation of the umbilical artery is reported by Rogers (1948) using amyl nitrite. This is confirmed by our findings with sodium nitrite.

Explanation for the absence of a constrictor action of angiotensin even in preparations which were markedly sensitive to catecholamines is not easily available. Somlyo et al. (1965) also observed slight or no response of the umbilical vessels to angiotensin. The polypeptide is a powerful vasoconstrictor, and the bulk of evidence to date suggests a strong direct musculotropic action in causing this effect, though a nerve mediated component of action has been demonstrated (Bickerton \& Buckley, 1961 ; Laverty, 1963; Robertson \& Rubin, 1962). The inactivity of angiotensin is probably due to absence of responsive sites in the umbilical artery for angiotensin.

Recent observations indicate that the placenta is less of a barrier to the passage of drugs than is generally thought (Baker, 1960). Most of the substances in maternal blood could thus have an access to the umbilical circulation (Moya \& Thorndyke, 1962), though precise quantitative information on the kinetics of this process is not available. Umbilical circulation, which constitutes the single most important determinant of systemic vascular resistance within the foetal circulation (Dawes, 1962) is thus vulnerable to potent vasoactive agents, including powerful biogenic substances.

Our finding that catecholamines can constrict the umbilical artery in small doses has significance in view of the release of the amines in vivo during conditions of foetal hypoxia and asphyxia demonstrated by Comline \& Silver (1961).

Large doses of 5-hydroxytryptamine result in foetal death in mice through toxic action on the placenta (Robson \& Senior, 1964 ; Robson \& Sullivan, 1963). In view of the very high sensitivity of umbilical vessels to 5-hydroxytryptamine, constriction of umbilical vessels cannot be ruled out as a cause of foetal death. 5-hydroxytryptamine liberated from platelets is also implicated in the spontaneous closure of umbilical vessels after 
birth (Rodegra, Roeder, Schmermund \& Soehring, 1957). The same function could now be suggested for other potent biogenic vasoactive substances like adrenaline, histamine and bradykinin.

\section{SUMMARY}

1. Constrictor and dilator responses elicited by a number of vasoactive substances were examined on the isolated perfused, non-innervated human umbilical artery.

2. Acetylcholine usually produced either a constrictor or a dilator response which was blocked by atropine or hyoscine but not by antazoline. Physostigmine did not modify the effects of acetylcholine.

3. Adrenaline and noradrenaline produced either a constriction or a dilatation of the vessel in most of the preparations. Both the constrictor and the dilator responses were blocked by dihydroergotamine or phentolamine, but not by atropine or antazoline. The dilator response was not blocked by pronethalol. Isoprenaline did not cause a dilatation of the vessel. It is concluded that the human umbilical artery has no $\beta$-adrenergic receptor, and that both the constrictor and the dilator responses to adrenaline and noradrenaline are mediated through $\alpha$-adrenergic receptor activation.

4. 5-hydroxytryptamine caused a powerful constriction of the vessel which was blocked by BOL and cyproheptadine but not by atropine.

5. Histamine produced a powerful constriction which was often preceded by transient dilatation. The response was blocked by antazoline or mepyramine but not by atropine, phentolamine or dihydroergotamine.

6. Bradykinin caused a constriction of the vessel while angiotensin had no effect. The response to bradykinin was blocked by acetyl salicylic acid but not by phentolamine atropine, cyproheptadine or BOL.

7. Posterior pituitary extract produced a constriction of the vessel while synthetic oxytocin caused either a constriction or a dilatation; digoxin caused a constriction.

8. Barium chloride, calcium chloride and potassium chloride each caused a constrictor response which was related to dose.

9. Caffeine, aminophylline and sodium nitrite caused a dilatation of the umbilical artery while papaverine caused slight constriction.

Our thanks are due to Dr. A. D. Joseph, Dean of the Medical College, Baroda, for providing facilities to carry out this work. It is a pleasure to acknowledge the gifts of 5-hydroxytryptamine, bradykinin, oxytocin and bromolysergic acid diethylamide by Sandoz Ltd. (Basle); of ( \pm )-noradrenaline by Sigma Chemicals (St. Louis); of phentolamine and angiotensin by Ciba (Basle); of pronethalol by Mr. G. V. McHattie, I.C.I. Ltd. (Cheshire); of cyproheptadine by Marck Sharp \& Dohme (Bombay); and of mepyramine by May \& Baker (Bombay).

\section{REFERENCES}

Antonio, A. \& Rocha E. Silva, M. (1962). Coronary vasodilatation produced by bradykinin on isolated mammalian heart. Circulation Res., 11, 910-915.

Aström, A. \& SAmelrus, U. (1957). Action of 5-HT and some of its antagonists on the umbilical vessels of the human placenta. Br. J. Pharmac. Chemother., 12, 410-414.

BAKER, J. B. E. (1960). The effects of drugs on the foetus. Pharmac. Rev., 12, 37-90.

BICKERTON, R. K. \& BUCKLEY, J. P. (1961). Evidence for a central mechanism in angiotensin induced hypertension. Proc. Soc. exp. Biol. Med., 106, 834-836. 
Black, J. W. \& Stephenson, J. S. (1962). Pharmacology of a new adrenergic beta-receptor-blocking compound (Nethalide). Lancet, ii, 311-314.

BülbRING, E., BuRN. J. H. \& Shelley, H. (1953). Acetylcholine and ciliary movement in the gill plates of Mytilus edulis. Proc. R. Soc. B., 141, 445-466.

Clark, E. R. \& Clark, E. L. (1943). Caliber changes in minute blood vessels observed in the living mammal. Am. J. Anat., 73, 215-250.

COLLIER, H. O. J. (1963). The action and antagonism of kinins on bronchioles. Ann. N.Y. Acad. Sci., 104, $290-298$.

Collier, H. O. J., Holgate, J. A., Schachter, M. \& ShORLEy, P. G. (1960). The bronchoconstrictor action of bradykinin in the guinea-pig. Br. J. Pharmac. Chemother., 15, 290-297.

Collier, H. O. J. \& Shorley, P. G. (1960). Analgesic antipyretic drugs as antagonists of bradykinin. $B r . J$. Pharmac. Chemother., 15, 601-610.

ComLINE, R. E. (1946). Synthesis of acetylcholine by non-nervous tissue. J. Physiol. (Lond.), 105, 6-7P.

COMLINE, R. S. \& Silver, M. (1961). The release of adrenaline and noradrenaline from the adrenal glands of the foetal sheep. J. Physiol. (Lond.), 156, 424-444.

CORBIT, J. D. (1962). Effect of oxytocin on oxygen exchange between maternal and foetal circulation at the time of cesarean section. Am. J. Obstet. Gynec., 84, 1313-1315.

CroXAtto, H. \& BelMER, J. (1961). Hypertensive effects of bradykinin in rats. Nature (Lond.), 192, 879-880.

CUTHBERT, A. W. (1962). Actions of some anticholinesterases on the smooth muscle of the chick amnion. Br. J. Pharmac. Chemother., 18, 550-562.

Cuthrert, A. W. (1963). Some effects of atropine on smooth muscle. Br. J. Pharmac. Chemother., 21, 285-294.

Dawes, G. S. (1962). The umbilical circulation. Am. J. Obstet. Gynec., 84, 1634-1648.

VON EULER, U. S. (1938). Action of adrenaline, acetyl choline and other substances on nerve-free vessels (human placenta). J. Physiol. (Lond.), 93, 129-143.

FelDBERG, W. \& LIN, R. C. Y. (1950). Synthesis of acetylcholine in the wall of the digestive tract. J.Physiol. (Lond.), 111, 96-119.

FERGUSON, J. (1940). A study of nerve-free smooth muscle of the amnion of the chick. Am. J. Physiol., 131, 524-534.

FleisCH, A. (1931). Die Wirkung von Histamin, Acetylcholin und Adrenalin auf die Venen. Pflügers Arch, ges. Physiol., 228, 351-372.

Freyburger, W. A., Graham, B. E., RAPport, M. M., Saey, P. H., Govier, W. M., Swoap, O. F. \& Vander BROOK, M. J. (1952). The pharmacology of 5-hydroxytryptamine (Serotonin). J. Pharmac. exp. Ther., $105,80-86$,

FURCHGOTT, R. F. (1954). Dibenamine blockade in strips of rabbit aorta and its use in differentiating receptors. J. Pharmac. exp. Ther., 111, 265-284.

KonZETT, H. \& STÜRMER, E. (1960). Biological activity of synthetic polypeptides with bradykinin-like properties. Br. J. Pharmac. Chemother., 15, 544-551.

LAVERTY, R. (1963). A nervously-mediated action of angiotensin in anaesthetized rats. J. Pharm. Pharmac. $15,63-68$.

LEwIS, G. P. (1960). Active polypeptides derived from plasma proteins. Physiol. Rev., 40, 647-676.

MOYA, F. \& THORNDYKe, V. (1962). Passage of drugs across the placenta. Am. J. Obstet. Gynec., 84, 17781798.

NuKI, B. (1954). Pharmacology of pulmonary circulation. Jap. Circul. J., 18, 205-215.

PAGE, I. H. \& MCCuBbin, J. W. (1953). Variable arterial pressure response to serotonin in laboratory animals and man. Circulation Res., 1, 354-362.

Panigel, M. (1959). Contribution to the physiology of feto-placental circulation. J. Physiol. (Paris), 51, 941-969.

Panigel, M. (1962). Placental perfusion experiments. Am. J. Obstet. Gynec., 84, 1664-1683.

PARRATt, J. R. (1964). A comparison of the effects of the plasma kinins, bradykinin and kallidin, on myocardial blood flow and metabolism. Br. J. Pharmac. Chemother., 22, 34-46.

REID, G. \& RAND, M. (1952). Pharmacological actions of synthetic 5-hydroxytryptamine (serotonin, thrombocytin). Nature (Lond.), 169, 801-802.

Robertson, P. A. \& RUBin, D. (1962). Stimulation of intestinal nervous elements by angiotensin. Br. J. Pharmac. Chemother., 19, 5-12.

Robson, J. M. \& Senior, J. B. (1964). The 5-hydroxytryptamine content of the placenta and foetus during pregnancy in mice. Br. J. Pharmac. Chemother., 22, 380-391.

Robson, J. M. \& Sullivan, F. M. (1963). Mechanism of lethal action of 5-hydroxytryptamine on the foetus. J. Endocr., 25, 553-554.

RODEgra, H., ROEder, G., SCHMERMUND, H. J. \& SOEHRING, K. (1957). Wirkung von 5-Hydroxytryptamin auf die isolierte Nabel Schnurarterie (Effect of 5-hydroxytryptamine on the isolated umbilical cord artery). Naunyn-Schmiedberg's Arch. exp. Path. Pharmak., 232 (1), 285-286. 
Rogers, A. F. Cited by Baker, J. B. E. (1960). The effects of drugs on the foetus. Pharmac. Rev., 12, 37-90. Somlyo, A. V., Woo ChI-YuAN \& Somlyo, A. P. (1965). Responses of nerve-free vessels to vasoactive amines and polypeptides. Am. J. Physiol., 208, 748-753.

STÜRMER, E. \& BERDE, B. (1962). Kallidin und Bradykinin, vergleichende pharmakologische Untersuchungen. Naunyn-Schmiedeberg's Arch. exp. Path, Pharmak., 243, 355.

TAKENAKA, F. (1963). Response of vascular strip preparations to noradrenaline and tyramine. $J x p . J$. Pharmac., 13, 274-281.

UEDA, K. (1931). Pharmacological investigation of blood vessels of the human placenta. Part II. Supplementary information in the action of toxins of vegetative nerve upon the blood vessels of immature placentas in every stage of pregnancy and on the existence of vascular nerve in the said blood vessels. JaF.J. Obstet. Gynec., 15, 264-283. 